\title{
Optimizing an Aversion Feeding Therapy Protocol for a Child with Food Protein-Induced Enterocolitis Syndrome (FPIES)
}

\section{Rhonda Mattingly ${ }^{*}$, Vincent Mukkada ${ }^{2}$, Alan Smith ${ }^{1}$ and Teresa Pitts ${ }^{3}$}

${ }^{1}$ Department of Otolaryngology-Head and Neck Surgery and Communicative Disorders School of Medicine, University of Louisville, USA

${ }^{2}$ Gastroenterology, Hepatology, and Nutrition, Cincinnati Children's Hospital Medical Center, University of Cincinnati College of Medicine, USA

${ }^{3}$ Department of Neurological Surgery and Kentucky Spinal Cord Injury Research Center, School of Medicine, University of Louisville, USA

\begin{abstract}
This case study examines the difficulties of treating food aversion in a 9-month old child with a diagnosis of Food Protein-Induced Enterocolitis Syndrome (FPIES). Given the need to first identify a set of "safe foods" with which to work, the twin goals of doing food challenges and minimizing aversion are initially not complimentary, and require an approach outside the standard of care. The chosen plan encouraged flexibility and a positive relationship with feedingrelated items, while only introducing one food item at a time. Mom and child accomplished goals surrounding food play easily. She has successfully introduced a wide variety of new foods in small quantities and is currently working on reducing dependence on breast milk. Therapists must be prepared to modify currently accepted interventions to accommodate and support the required medical intervention.
\end{abstract}

Keywords: FPIES; Feeding aversion; Dysphagia

\section{Patient}

A 9-month old Caucasian female was referred for therapy due to initial concerns of difficulty transitioning from breast-feeding to cup. She was $7 \mathrm{lbs}-5 \mathrm{oz}$ at birth. At the initial visit with the speech-language pathologist she was $15 \mathrm{lbs} 3 \mathrm{oz}$ and this weight had reportedly been unchanged for 3 months. The child was born to middle-class parents and there was no history of feeding problems in the family. Cognition and motor skills were within normal limits, but the child was scheduled to receive occupational therapy services due to a delay in self-help skills, increasing oral facial aversion, poor sleep, and inability to be calmed by anyone other than her mother. She was also refusing to accept any stimulation around or in her mouth. Speech-language pathology services were ordered due to the child's increasing feeding aversion. Table 1 is a detailed list of hospitalizations and diagnosis, which led to therapy recommendations.

The food aversion was characterized by refusal of any oral liquid besides the breast, and was further complicated by severe reactions (primarily vomiting and diarrhea) to solid food presentation. These reactions resulted in three hospitalizations. She had an upper endoscopy during one of these episodes, with relatively normal appearing mucosa, and histologic findings of a non-uniform duodenitis with increased number of eosinophils (peak count of 83 with normal expected peak of 28) and some associated crypt abscesses. Given that this was done in the context of an active vomiting episode, this was felt to be most likely due to a reaction to food rather than a chronic eosinophilic gastrointestinal disease, and she was diagnosed with Food ProteinInduced Enterocolitis Syndrome (FPIES).

\section{Diagnosis}

FPIES is a non-immunoglobulin E-mediated food allergy affecting the gastrointestinal tract [1]. The etiology of FPIES is not well understood. Antigen-specific $\mathrm{T}$ cells, antibodies and cytokines lead to inflammation causing decreased mucosal barrier function and increased fluid losses into the gut lumen [2]. Symptoms of acute FPIES may include severe vomiting, diarrhea (frequently bloody), dehydration and lethargy, frequently leading to shock requiring hospital admission. Chronic cases are associated with less severe vomiting and loose stools, feeding problems and failure to thrive. Recent studies [1] suggest a higher incidence of FPIES than once thought. A large Israeli population-based birth cohort found that 0.34 percent of infants ( 44 of 13,019) was diagnosed with FPIES [3]. Making the FPIES diagnosis is challenging due to the lack of a gold-standard diagnostic test because of this, it is a clinical diagnosis that can be easily missed without a careful diet history. More recent focus on the acute phenotype has led to more children being identified and a possible reduction of chronic cases due to the availability of hypoallergenic formulas [1].

FPIES is associated with oral feeding aversion and delay. Feeding disorders are quite common in children, with reported incidence of minor problems ranging between $25-35 \%$, and upwards of $40-70 \%$ in premature infants or children with chronic medical conditions [4]. In this case, the intersection between early gastrointestinal issues and feeding aversion is quite complicated. The early food related restrictions reduce the child's natural interaction with food, environment, and family. In fact, feeding difficulties are often associated with food allergies, and they are now included in the National Institute of Clinical Excellence guidelines in the United Kingdom as a possible symptom to assist in the diagnosis of non-IgE mediated allergies affecting the gastrointestinal tract [5].

Therapeutic intervention for infants and children with feeding problems focuses on either developing the oral motor skills necessary to tolerate a varied diet and/or the sensory flexibility to accept an adequate variety to support nutritional intake. Underlying medical, social, developmental, and cognitive issues also impact outcomes. Food chaining is a widely used protocol in which attributes of accepted foods are gradually used to increase the child's acceptance of a wider repertoire of foods [6]. Restrictions external to those the child places on himself through aversion and avoidance (as, for instance, in the case of foods that need to be avoided due to their risk of triggering an immunologic reaction) can multiply the difficulty when attempting to

*Corresponding author: Rhonda Mattingly, Assistant Professor and Clinical Director, Speech-Language Pathology, University of Louisville, USA, Tel: 502-852-0347; E-mail: rrmatt02@louisville.edu

Received April 27, 2015; Accepted August 18, 2015; Published August 25, 2015

Citation: Mattingly R, Mukkada V, Smith A, Pitts T (2015) Optimizing an Aversion Feeding Therapy Protocol for a Child with Food Protein-Induced Enterocolitis Syndrome (FPIES). J Pulm Respir Med 5: 287. doi:10.4172/2161-105X.1000287

Copyright: (c) 2015 Mattingly R, et al. This is an open-access article distributed under the terms of the Creative Commons Attribution License, which permits unrestricted use, distribution, and reproduction in any medium, provided the original author and source are credited. 


\begin{tabular}{|c|c|c|c|c|c|c|}
\hline Age & Location & Provider & $\begin{array}{l}\text { Precipitating } \\
\text { Symptoms }\end{array}$ & Tests/Diagnosis & Medications & Recommendations \\
\hline 6.5 months & $\begin{array}{l}\text { Physician's } \\
\text { office }\end{array}$ & Pediatrician & $\begin{array}{l}\text { Difficulty transitioning to } \\
\text { rice or oat cereal. }\end{array}$ & FPIES & None & $\begin{array}{l}\text { Refer to Pediatric } \\
\text { Gastroenterologist. }\end{array}$ \\
\hline 6.8 months & Hospital & Pediatrician & $\begin{array}{l}\text { Emesis/diarrhea for } 2 \\
\text { days; post ingestion of } \\
\text { carrot }\end{array}$ & $\begin{array}{l}\text { Dehydration, emesis, diarrhea } \\
\text { secondary to FPIES }\end{array}$ & $\begin{array}{l}\text { Lansoprazole (Prevacid) } 3 \\
\mathrm{mg} / \mathrm{mL} \text {, and ondansetron } \\
\text { (Zofran) } 4 \mathrm{mg} / 5 \mathrm{~mL} .\end{array}$ & $\begin{array}{l}\text { Continue advancement } \\
\text { of infant diet, Zofran } \\
\text { prn, and speech therapy } \\
\text { consult. }\end{array}$ \\
\hline 7 months & Hospital & $\begin{array}{l}\text { Pediatrician } \\
\text { and pediatric } \\
\text { gastroenterologist }\end{array}$ & $\begin{array}{l}\text { Emesis of bright yellow } \\
\text { color and diarrhea post } \\
\text { breastfeeding }\end{array}$ & $\begin{array}{l}\text { 1. Upper GI test: nonsignificant } \\
\text { pylorospasm with delayed } \\
\text { gastric emptying; } 2 \text {. Mild } \\
\text { erythema of the body of the } \\
\text { stomach }\end{array}$ & $\begin{array}{l}\text { Esomeprazole (Nexium) } \\
5 \mathrm{mg} \text {, daily for } 30 \text { days; } \\
\text { ondansetron (Zofran) } 4 \\
\mathrm{mg} / 5 \mathrm{~mL} \text {, every } 8 \mathrm{hrs} \text { for } \\
4 \text { days. }\end{array}$ & $\begin{array}{l}\text { Discontinue the Zantac, } \\
\text { and avoid new foods until } \\
\text { follow-up with GI. }\end{array}$ \\
\hline 7.1 months & Hospital & $\begin{array}{l}\text { Pediatrician } \\
\text { and pediatric } \\
\text { gastroenterologist }\end{array}$ & $\begin{array}{l}\text { Reoccurrence of emesis } \\
\text { and diarrhea }\end{array}$ & $\begin{array}{l}\text { 1. MRI brain: no evidence of } \\
\text { mass lesion or increased intra- } \\
\text { cranial pressure; } 2 \text {. GI biopsy: } \\
\text { duodenal eosinophilia. }\end{array}$ & $\begin{array}{l}\text { *Orapred } 1 \text { mg/kg BID for } \\
6 \text { weeks. }\end{array}$ & $\begin{array}{l}\text { Mother's diet restricted } \\
\text { from dairy and soy. }\end{array}$ \\
\hline 9.1 months & Home & $\begin{array}{l}\text { Speech-Language } \\
\text { Pathologist }\end{array}$ & $\begin{array}{l}\text { Feeding aversion and } \\
\text { refusal to accept liquid } \\
\text { except directly from the } \\
\text { breast }\end{array}$ & $\begin{array}{l}\text { Feeding Aversion and Delayed } \\
\text { Oral Motor Feeding Skills }\end{array}$ & None & $\begin{array}{l}\text { Initiate plan to encourage } \\
\text { increased flexibility } \\
\text { around food, liquid, and } \\
\text { food-related items }\end{array}$ \\
\hline 10.26 months & Hospital & $\begin{array}{l}\text { Pediatric } \\
\text { Gastroenterologist } \\
(\mathrm{VM})\end{array}$ & $\begin{array}{l}\text { Continuation of } \\
\text { previous symptoms and } \\
\text { management of disorder }\end{array}$ & FPIES & $\begin{array}{l}\text { Continue Zofran prn, } \\
\text { Zantac prn }\end{array}$ & $\begin{array}{l}\text { Trial elemental formula, } \\
\text { Referral to allergist to } \\
\text { consider food challenge, } \\
\text { Initiate pears }\end{array}$ \\
\hline
\end{tabular}

*Steroids are not typically indicated in the treatment of FPIES, but in this patient given the severity of her illness and the possible diagnosis of eosinophilic duodenitis a decision was made to do a prolonged course of swallowed corticosteroids.

Table 1: Summary of significant medical events prior to starting speech/feeding therapy.

increase flexibility and variety of intake. The Sequential Oral Sensory Approach is also a frequently used program to treat children with feeding difficulties including aversion. This treatment method is based on the understanding that infants and children develop a relationship with food through the Steps to Eating Hierarchy. For example, before a child tastes food he must be able to tolerate it in the room, touch it, and smell it. Through the process of systematic desensitization and in the context of the hierarchy infants and children begin to interact with and eat a wider variety of foods without anxiety [7]. The foundation of this program is also linked to increasing a child's flexibility and comfort with interacting with new foods. In conjunction with the hierarchy concept it is understood that infants are born with reflexes that support oral feeding. These reflexes evolve into mature skills based on the experiences the infant has with his environment and feeding [8]. Medical issues, developmental delays, and sensory problems can negatively impact feeding development and contribute to feeding disorders [9]. Food restrictions necessary to diagnose and treat FPIES using the initial elimination diet and gradual oral food challenge further limit the variety of nutrition to which the child is exposed. Negative reactions that occur as the child potentially reacts to re-introduced foods reinforce aversive behaviors. For this reason it is critical that providers understand the importance of appropriate feeding therapy in the form of encouraging oral motor skill development, flexibility, social acceptance of snack time and meal time activities, shaping of a positive relationship with safe foods, and extensive parent education.

Though the prognosis for children with FPIES is favorable, in that it typically resolves by $3-5$ years of age $[1,10,11]$ the impact of the disorder results in decreased opportunities to practice oral motor skill development with a variety of foods and can result in learned feeding aversion. Even in children with nonorganic feeding problems who are still able to thrive nutritionally, negative behaviors around feeding can result in a greater risk for poor health, social and emotional problems, nutrient deficiencies, social problems, and disruption of family life [12].

\section{Treatment Plan}

Medical therapy in FPIES is focused on food challenges to identify a list of tolerated foods, while trying to minimize food avoidance. Unfortunately, to this point the available clinical allergy tests have not reliably identified trigger foods, resulting in the need for food challenges that are often laborious and time-consuming. Due to the potential severity of the reactions, the food challenges require one food to be presented each week (i.e., pears), and in a large enough quantity to assess the child's response. Conversely, traditional food aversion therapy includes familiarizing the child with a wide variety of food and textures, chaining from an already accepted food to new foods, and providing social feeding experiences, with no restrictions on the amount of foods to be introduced in a given time. Given the need to first identify a set of tolerated foods with which to work, the twin goals of doing food challenges and minimizing aversion can initially be counterproductive, and require an approach outside the standard of care.

Our feeding treatment plan encouraged flexibility and a positive relationship with feeding-related items and was presented as follows:

A. Obtaining toy food so the infant would become familiar with the visual representation of edible items and including utensils, cups, and dishes in a variety of play.

B. Offering water via spoon, and if accepted increasing to straw and sippy cup.

C. Neocate Nutra, a hypoallergenic, semi-solid medical food designed for individuals needing elemental formula due to severe food allergies was presented.

D. Presentation of Elecare (an elemental formula which would be a safe alternative as mother was weaning from breast milk-her mother was also doing a strict elimination diet to minimize potentially harmful antigens in the breast milk) from a cup and a spoon.

E. Presentation of Neocate Jr Vanilla (another elemental formula for children for the dietary management of cow milk allergy, multiple food protein intolerance and food-allergy-associated conditions) from a cup, a spoon, and made as a pudding.

F. Present first food item for allergy testing (in this case, pears on 
week 1 , followed by apples, green beans, green pepper, asparagus, etc. in subsequent weeks). This includes presentation in as many forms (i.e. frozen, pureed, cooked, raw, made into crispy "chips, etc.) of the food as available.

G. Present second food item one week later, and continue on with food challenges as directed by the physician.

If negative physiological responses to food occurred the food was discontinued. If the child rejected a food it was presented again, sometimes in other forms, on several occasions. Preferred and tolerated foods were continually offered but would initially be withheld to permit the child an opportunity to interact with new food. Breast-feeding was maintained throughout to allow the child to remain hydrated and to take in nutrition. The mother's diet was restricted due to concerns that the child would react to foods with higher risk for a negative response. Avoided foods included rice, oats, carrots, nuts, grains, soy, and dairy.

\section{Results}

Mom and child accomplished goals surrounding food play easily. She showed significant interest and mouthed all items. The patient demonstrated significantly delayed oral motor skills which made straw/sippy cup drinking difficult, however aversion to non-breast presentation was significantly decreased. The Neocate Nutra ${ }^{\circledR}$ (Nutricia North America; Gaithersburg, MD), and Elecare (Abbott Nutrition; Columbus, $\mathrm{OH}$ ) were rejected in their original form.

First food item presentations included: sliced fresh, fruit peel, freeze dried (regular dried could not be used due to preservatives), liquid, and frozen (in slushy and solid form). Presentation environments included a high chair in the kitchen, living room floor, and in the bathtub (Figure $1)$.

The patient was willing to mouth slices, drink from a cup, and attempted to manage freeze-dried pieces. Due to her oral motor skills delay she was not adequately able to manage the pieces so it was initially recommended that they be placed in a feeder bag until she could develop adequate skill. She could not tolerate pieces so we used a feeder bag, which she rejected, so we went back to pieces, which she eventually accepted. Following acceptance of pieces she then began accepting thick strips of the peel, which she mouthed and then discarded.

The traditional week timeframe for new foods was modified due to her food aversion, and has been extended to two-three weeks to allow for adequate assessment of each food item. This timeframe can be accelerated to the 1-week standard with increased food acceptance.

\section{Practice Implications/Conclusions}

Other non-IgE mediated disorders such as food protein-induced allergic proctocolitis and food protein-induced enteropathy have similar if less severe symptomology than FPIES and are diagnosed clinically based on elimination diets followed by reintroduction of suspicious foods. Though a separate clinical entity, eosinophilic gastroenteropathies share many overlapping clinical and histological features with the non-IgE gastrointestinal food allergies [11]. EGs include eosinophilic proctocolitis (EP), eosinophilic gastroenteritis (EG), and eosinophilic esophagitis (EoE). Diagnosis of EP is primarily made clinically while some lab parameters and diagnostic tests including endoscopy may be helpful in diagnosing EG, and upper endoscopy with biopsy is necessary to definitively diagnose EoE [3]. Gastrointestinal symptoms are characteristic of EGs and treatment can include restricting the diet with a gradual reintroduction to determine the offending foods [3]. Dysfunctional feeding is a frequently
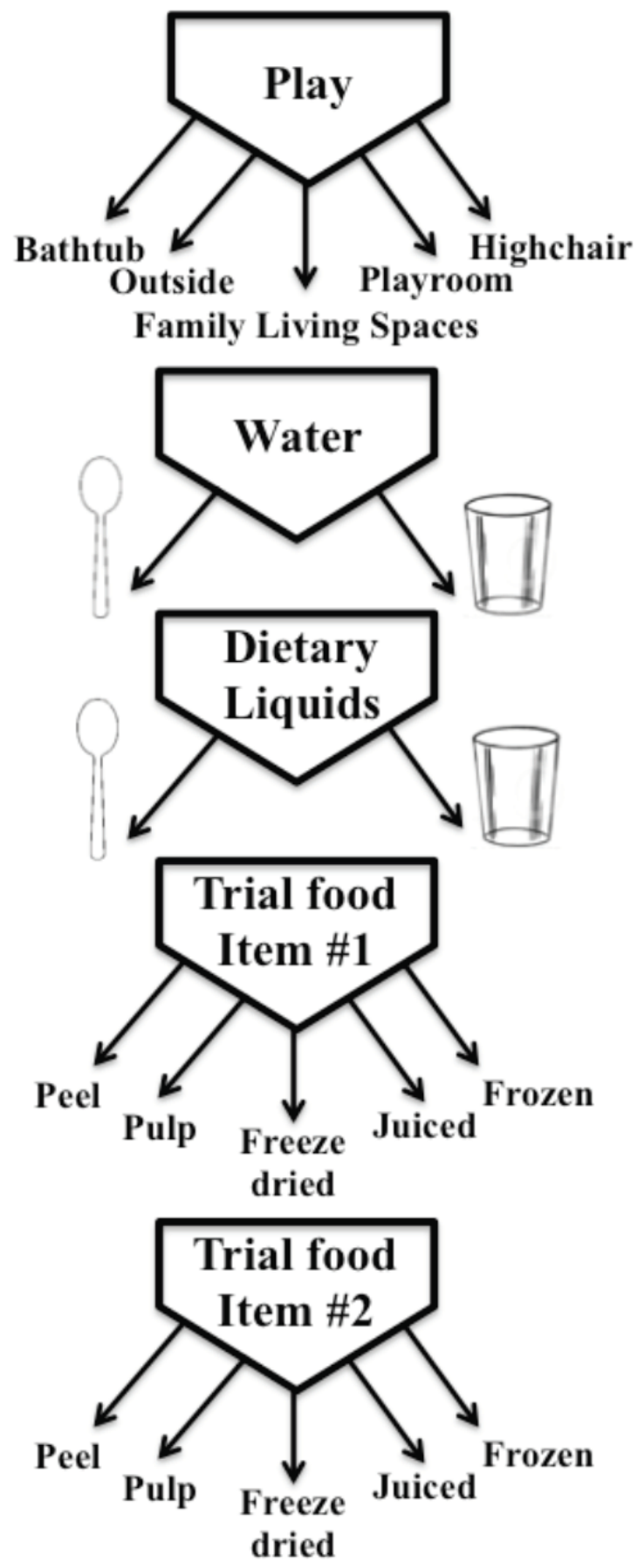

Figure 1: The therapy schematic is additive function, as you move from one stage to the next, while using all tools at the therapist disposal. We recommend that the child spends at least 1 week in every phase. Note that play is not for purposes of distracting the child, but to involve them in the food based activity. Water can be phased out if the child is advancing, however it may be necessary to continue because it may be less threatening. The physician must be involved in the food trial choices and the amount of time necessary to spend in these particular phases.

occurring symptom associated with EoE [13-15] with similar potential complications relating to therapy. Given the existence of these other similar diseases with their associated risk for feeding dysfunction, we would argue that the concepts illustrated in this patient with FPIES may 
have broad applicability to a range of food-allergic conditions.

In summary, feeding aversion has a profound impact on children and their families regardless of etiology. The presence of a medical problem may exacerbate the aversion and concurrently restrict the use of typical therapeutic interventions. In fact, clinical treatment of the underlying medical disorder can interfere with the feeding therapy process and make the situation more complex. Therapists must be prepared to modify currently accepted interventions to accommodate and support the required medical intervention.

\section{Grants}

NIH Institute of Heart, Lung and Blood HL111215.

\section{References}

1. Mehr S, Frith K, Campbell DE (2014) Epidemiology of food protein-induced enterocolitis syndrome. Curr Opin Allergy Clin Immunol 14: 208-216.

2. Leonard SA, Nowak-Węgrzyn A (2012) Clinical diagnosis and management of food protein-induced enterocolitis syndrome. Curr Opin Pediatr 24: 739-745.

3. Liacouras CA, Furuta GT, Hirano I, Atkins D, Attwood SE, et al. (2011) Eosinophilic esophagitis: updated consensus recommendations for children and adults. J Allergy Clin Immunol 128: 3-20.

4. Rudolph CD, Link DT (2002) Feeding disorders in infants and children. Pediatr Clin North Am 49: 97-112, vi.

5. Sackeyfio A, Senthinathan A, Kandaswamy P, Barry PW, Shaw B, et al. (2011) Diagnosis and assessment of food allergy in children and young people: summary of NICE guidance. BMJ 342: d747.

6. Fraker $C$, Walbert $L$ (2011) Treatment of selective eating and dysphagia using pre-chaining and food chaining $\odot$ therapy programs. SIG 13 Perspectives on Swallowing and Swallowing Disorders (Dysphagia) 20: 75-81.

7. Toomey KA, Ross ES (2011) SOS Approach to feeding. SIG 13 Perspectives on Swallowing and Swallowing Disorders (Dysphagia) 20: 82-87.

8. Morris SE, Klein MD (2000) Pre-feeding skills: a comprehensive resource for mealtime development: Pro-ed.

9. Overland L (2011) A sensory-motor approach to feeding. SIG 13 Perspectives on Swallowing and Swallowing Disorders (Dysphagia), 20: 60-64.

10. Nowak-Wegrzyn A, Muraro A (2009) Food protein-induced enterocolitis syndrome. Curr Opin Allergy Clin Immunol 9: 371-377.

11. Feuille E, Nowak-Wegrzyn A (2015) Food Protein-Induced Enterocolitis Syndrome, Allergic Proctocolitis, and Enteropathy. Current allergy and asthma reports 15: 1-11.

12. Romano C, Hartman C, Privitera C, Cardile S, Shamir R (2015) Current topics in the diagnosis and management of the pediatric non organic feeding disorders (NOFEDs). Clin Nutr 34: 195-200.

13. Capocelli KE, Fernando SD, Menard-Katcher C, Furuta GT, Masterson JC et al. (2014) Ultrastructural features of eosinophilic oesophagitis: impact of treatment on desmosomes. J Clin Pathol 68: 51-56.

14. Mukkada VA, Haas A, Maune NC, Capocelli KE, Henry M, et al. (2010) Feeding dysfunction in children with eosinophilic gastrointestinal diseases. Pediatrics 126: e672-677.

15. Pentiuk SP, Miller CK, Kaul A (2007) Eosinophilic esophagitis in infants and toddlers. Dysphagia 22: 44-48. 